\title{
HIGHLIGHTS OF ISAD BOARD MEETING
}

\author{
1974 Midwinter Meeting \\ Chicago, Illinois
}

\section{Monday, January 21, 1974}

The meeting was called to order at 10:15 a.m. by President Frederick Kilgour. Those present were: BOARD-Frederick G. Kilgour, Lawrence W. S. Auld, Paul J. Fasana, Donald P. Hammer (ISAD Executive Secretary), Susan K. Martin, Ralph M. Shoffner, and Berniece Coulter, Secretary, ISAD. GUEST-Brett Butler.

MIDWINTER 1973 MINUTES APPROVED.

MOTION. Mr. Shoffner moved to approve the minutes of the Midwinter 1973 Board Meetings. SECONDED by Mr. Fasana. CARRIED.

LAS VEGAS ANNUAL MEETING MINUTES ACCEPTED. A correction on page one of the Las Vegas Annual Meeting Minutes was noted: Mr. Auld's name should be added to the list of guests present.

MOTION. Mr. Fasana moved that the minutes of the ISAD Board meetings at the Las Vegas Annual Conference be accepted as corrected. SECONDED by Mrs. Martin. CARRUED.

ISAD HISTORY COMMITTEE. The matter of appointing members to the ISAD History Committee, whose function is to prepare a history of ISAD for ALA's Centennial celebration in 1976, was considered.

Mr. Shoffner said that during the time he was president, he had rendered the ISAD History Committee inactive. It was suggested by Mr. Kilgour that a historian would serve the purpose better than a committee. Mr. Shoffner remarked that he anticipated the chairman would be a historian. Mrs. Martin asked whether a check could be made first whether ALA is planning to publish any document for the Centennial celebration that would make any preparation by an ISAD committee or historian worth while.

Mr. Kilgour remarked that ISAD definitely should be included if ALA did plan to publish any document and asked the board to give an "OK" to appoint a historian.

MOTION. Mr. Fasana moved that the ad hoc ISAD History Committee 
be abolished and recommended that the president be given the right to appoint a historian if ALA planned to publish a Centennial document. SECONDED by Mr. Auld. CARRIED.

ALA DUES STRUCTURE. Mr. Hammer explained the information submitted to the board concerning the proposed ALA dues structure. The basic fee for ALA membership under this proposed dues structure would be $\$ 35$. Membership in each division would be an additional $\$ 15$. In essence, each division would be on its own financially. If there are not enough memberships to support a division, as could be the case, the division would cease to exist.

ISAD could support itself with its present membership, but there is no. way of knowing how many ISAD members would still select ISAD if the choice of two divisions included in the dues was removed. The divisions that publish a journal would attract membership much more easily than those that do not provide a journal. Mr. Hammer further remarked that the proposed dues schedule indicates that the divisions must prove themselves with membership dues as their only support, but this does not apply to ALA Committees, SCMAI, units such as the Office for Intellectual Freedom, Office for Library Service to the Disadvantaged, and the administrative and support units of ALA. These units may be of great value to ALA, but if one unit is forced to prove its value financially, then it seems that all should have to prove themselves.

The divisions would be expected to depend on their own resources, e.g., if the division runs out of postage money, there would be no further mailings. The divisions would be expected to pay for their support services. The idea is very close to the federation plan which has been circulated for some time. In answer to the question of how a new division would get started, Mr. Hammer replied that he assumed there would have to be enough memberships to provide for it financially.

Mr. Shoffner suggested that the discussion be divided into two parts: (1) the principle involved; and (2) the financial aspect.

The following points were brought up in the ensuing discussion by the board regarding the proposed dues structure:

Starting a new division could be a problem; perhaps it could be subsidized for a stated time, after which the division would be self-sufficient. The proposed separation of dues, however, would force a clarity in expenditures of ALA in respect to how the divisions would benefit.

Some divisions could not be self-supporting and yet are producing important contributions for ALA.

A division would be at the mercy of the ALA supporting units. If a support unit was not efficient, the divisions would be handicapped in the services to their members.

Would a division be able to know enough in advance how much money could be counted on for program planning? The answer was "yes" based 
on past membership, except in the first year. The income would be predicted on the basis of the previous year's income. An excess of income would remain in the division's funds. If the division income fell short of the anticipated amount, it would have no back-up from ALA as it has presently.

A person could not join one or more of the divisions without joining ALA.

Some divisions could become part of a stronger division, e.g., a division could be broken up and absorbed into several other divisions with related interests. Was there any plan to absorb or redirect these divisions which obviously could not be self-supporting? Nothing has been announced so far.

If a division got into financial difficulties, it could not cut down on its professional staff as a professional staff is needed to maintain ALA's status with the Internal Revenue Service. It was noted that there were more important reasons than this for maintaining a professional staff.

This proposal was drafted by the then Deputy Director Ruth Warncke in 1970. The board was informed that a cost study of ALA was recently discussed by staff members, but the reply has been that it would take five years to make such a study. The ISAD Board disagreed with the period of five years, but stated that it could take a year.

A division should be allowed to set up its own budget under this proposal as well as have a voice in ALA policy.

The proposal appeared to be unfair in some points: (1) some divisions would have about twice their present income through memberships, while ISAD would break about even; (2) life members would be entitled to membership in all divisions; (3) apparently institutions without a group insurance plan of their own could join ALA for $\$ 35$ and be entitled to the group insurance for their staffs; at some point an examination of the privileges in each category of membership should be made; and (4) if the $\$ 35$ ALA membership fee were increased in the future, this would directly affect membership in the divisions.

The ISAD budget for the $1973 / 74$ year is approximately $\$ 47,000$ and the Journal of Library Automation $\$ 23,000$, or a total of approximately $\$ 70,000$. If ISAD membership should fall back to 3,000 members and the membership fee were $\$ 25$, ISAD could still be viable.

Mr. Kilgour's poll of the board revealed all were in favor of the principle of more or less independent divisions, but with reservations. The following was therefore moved:

MOTION. Mr. Shoffner moved that the ISAD Board favors the principle of divided annual fees for ALA and for its divisions subject to: (1) division determination of the fee structure for division memberships and publications; (2) division participation in the governance of ALA Headquarters activities. SECONDED by Mr. Fasana. MOTION CARRIED.

SELECTIVE DISSEMINATION OF INFORMATION SYSTEM. Mr. 
Hammer presented a proposal for establishing on a subscription basis a Selective Dissemination of Information system for ALA members (see Exhibit 1). After discussion it was decided that Mr. Hammer would contact Ohio State University library and obtain information on exact procedure as to how this would be run, how it would be publicized, who would develop the profiles, who would handle the subscriptions, the cost to the division, etc., and then report to the board.

CO-SPONSORSHIP OF BASIC DATA PROCESSING SEMINARS. $\mathrm{Mr}$. Hammer presented a proposal to the board regarding co-sponsorship of basic data processing seminars with organizations outside ISAD, such as IBM and Dataflow Systems, Inc. in Bethesda, Maryland. In the past ISAD seminars have generally been on library applications, but what he had in mind, Mr. Hammer said, was primarily on the basics of data processing, systems analysis, and other basic aspects that would be of interest to administrators. The intent would be to give administrators enough knowledge so that they could evaluate the results that they should be gaining from their data processing systems. These institutes would be a package deal in that the personnel and materials would be commercially supplied, Dataflow has conducted seminars for the United States Civil Service Commission. IBM has some seminars which are free, but there is a charge if they have to develop a special program. Comment was made regarding seminars conducted several years ago where problems developed as to the commercial aspects.

MOTION. It was moved by Mrs. Martin that the matter of ISAD's cosponsoring basic data processing seminars with outside organizations be referred to the ISAD Program Planning Committee for discussion and their evaluation. SECONDED by Mr. Fasana. CARRIED.

\section{Tuesday, January 22, 1974}

The meeting was called to order by the president, Mr. Kilgour, at 2:25 p.m. Those present were: BOARD-Frederick G. Kilgour, Lawrence W. S. Auld, Paul J. Fasana, Donald P. Hammer (ISAD Executive Secretary), Susan K. Martin, Ralph M. Shoffner, and Berniece Coulter, Secretary, ISAD. GUESTS-Alex Allain, Brigitte Kenney, Ron Miller, and Velma Veneziano.

DRAFT ON ALA GOALS AND OBJECTIVES. Mrs. Brigitte Kenney sought feedback from the board on the paper previously distributed on the ALA Committee on Planning's Draft Statement on ALA's Goals and Objectives. Several changes were suggested. Mrs. Kenney expressed her appreciation for their input.

FREEDOM TO READ FOUNDATION. Mr. Alex Allain from the foundation presented the cause of the Freedom to Read Foundation in re- 
gard to the current problem of censorship. He stressed the desire to keep channels open with the divisions of ALA and with systems and networks across the nation.

MARBI AND ISAD STANDARDS COMMITTEE (TESLA). Velma Veneziano, chairman of the MARBI Interdivisional Committee, appeared before the ISAD Board requesting clarification of the functions of MARBI and the ISAD Standards Committee (TESLA). She said that her committee would like discrepancies cleared up and duplications eliminated. Mrs. Martin suggested that the charges to both MARBI and TESLA be reworded to clarify their functions.

ISAD BYLAWS COMMITTEE. In response to discussions concerning the establishment of several committees, Mr. Shoffner Moved to establish an Organization Committee. SECONDED by Mrs. Martin.

Mr. Fasana pointed out that the mechanism for establishing a Bylaws Committee was already spelled out in the ISAD constitution. The president can appoint the committee.

MOTION WITHDRAwN. Mr. Shoffner withdrew his motion.

Mr. Fasana suggested that the Bylaws Committee also be charged with the organizational and review function. The matter of the Standards Committee's function was also made the charge of the Bylaws Committee.

\section{Wednesday, January 23, 1974}

President Kilgour called the meeting to order at 10:15 a.m. Those present were: BOARD-Frederick G. Kilgour, Lawrence W. S. Auld, Paul J. Fasana, Donald P. Hammer (ISAD Executive Secretary), Susan K. Martin, Ralph M. Shoffner, and Berniece Coulter, Secretary, ISAD. GUESTSBrett Butler, John Kountz, Ann Painter, Charles Payne, James Rizzolo, Richard Utman, Velma Veneziano, and David Waite.

REPORT OF THE NOMINATING COMMITTEE. The chairman, Charles Payne, announced the nominees for the 1974/75 slate of ISAD candidates:

Vice-President/President-Elect: Henriette Avram Allen Veaner

Board Member-at-Large: Ruth Tighe Maurice Freedman

The board members extended a vote of thanks to the Nominating Committee for their work.

REPORT OF MARC USER'S DISCUSSION GROUP. Mr. James Rizzolo, chairman, said most of the discussion in the discussion group revolved around ALA, CLR, and the change in CLR's status which was moved in August from one IRS classification to another. It is now an "op- 
erating foundation," i.e., it is active in programs rather than waiting for a reaction to a request using funds they have as a "carrot." Also discussed was whether CLR should fund and pick the participants or CLR should do the funding and ALA pick the participants.

Also the group considered the question of standards and how one arrives at them. There are a number of groups in ALA dealing with standards, but there is a need to work out a systematic method of developing standards. There needs to be a routine mechanism set up for going from an initial formulation of an idea for a standard to a standard that the profession can live with.

REPORT OF PROGRAM PLANNING COMMITTEE. The committee met at the ASIS meeting in Los Angeles prior to meeting at the ALA Midwinter Meeting.

Mr. Brett Butler, chairman, announced that three European librarians had been invited to participate in the 1974 Annual Program at New York City. Mr. Kilgour was handling all arrangements. Mr. Kilgour informed the board that the travel expenses of all three librarians were being provided for by sources outside ALA.

Linda Crismond is the local planning person for the 1975 San Francisco Annual Conference program which will be sponsored jointly with ASIS. Joshua Smith had suggested Mark Radwin of Lockheed as liaison and he had agreed to serve in this capacity.

The New Orleans institute on "Alternatives in Bibliographic Networking" had enough registrants by Midwinter to confirm it. There had been some difficulty concerning contact with speakers but the details had been straightened out. Copies of the program for the New Orleans institute were distributed.

Mr. Butler also informed the board that his committee was looking into the details of cooperating with other institutions and state schools which might be interested in working with ISAD in a seminar or institute. The committee was also considering what type of programs should be presented, subcontracting to outside companies, and how to control these. The members of the committee were working on a procedure manual for use in conducting institutes.

TELECOMMUNICATIONS COMMITTEE REPORT. The activities of the Telecommunications Committee are highly organizational at present. The committee has swung away from Cable TV as its primary interest and towards telecommunications as applied to bibliographic networks.

The chairman, David Waite, said there was a need to set up a simple guide to carry out their charge for the educational activities and legislation advisory responsibilities to the ALA Committee on Legislation. More people would probably be appointed to the Telecommunications Committee as there was a need for more expertise to assign to the areas identified by the committee. 
He further said that the need now is to determine what existing apparatus may be utilized to fulfill the committee's responsibility to disseminate information regarding telecommunications as applied to the library community so that the committee could put most of its effort into technical work.

One project discussed was to gather background information on bibliographic data centers and network activities and their needs for telecommunication facilities in order to draft a requirements statement. The purpose of such a statement is that the committee could communicate with new telecommunications systems. The committee was not aware of an adequate statement of library requirements that is readily available for the commercial services that are steadily increasing.

Assignments have been given to Gordon Randall, Maryann Duggan, and Ron Miller to gather this information.

Mr. Waite remarked that the committee would be interested in any report on the proposed ISAD networks committee when available. Brett Butler, chairman of the Program Planning Committee, suggested that a telecommunications institute should be in the future plans and Mr. Waite's or any of his committee members contribution of any ideas about such would be appreciated.

REPORT OF THE INTERDIVISIONAL COMMITTEE ON MACHINE-READABLE BIBLIOGRAPHIC INFORMATION (MARBİ). (See Exhibit 2.) Mr. Kilgour appointed Velma Veneziano to serve as liaison to the ISAD Standards Committee from MARBI. Her term as chairman of MARBI will conclude in June 1974.

\section{REPORT OF COLA DISCUSSION GROUP. (See Exhibit 3.)}

REPORT OF COMMITTEE ON TECHNICAL STANDARDS FOR LIBRARY 'AUTOMATION (TESLA)." (See Exhibit 4.)-Report of Chairman John Kountz.

TECHNOLOGICAL UNEMPLOYMENT. President Kilgour felt ALA should do something about the spreading of unemployment due to increased use of technological development.

Mr. Auld suggested that someone be appointed to study the potential and existing problems in this area. This could be funded either: (1) under a fellowship by CLR; or (2) application for the J. Morris Jones Goals Award.

Mr. Fasana thought an interdivisional committee might be set up between the four most directly affected divisions: ISAD, LAD, LED, and RTSD.

Mr. Shoffner expressed his view that as efficiency is increased productivity is increased and could possibly therefore increase employment. Mr.: Kilgour said that history had proved to the contrary. Mr. Shoffner stated he felt the problem was one of education and training. A specification of 
what is expected of one and what training he would receive during a technical changeover was needed.

Mr. Fasana's suggestion was that the four divisions be asked for papers of their views or a program at the San Francisco Annual Conference be prepared on the subject of technological unemployment. Mr. Auld asked if it could not rather be introduced at the New York Annual Conference, to which Ann Painter volunteered the use of the ISAD/LED Education Committee's two-hour time slot for the program at New York.

MOTION. Mr. Fasana moved that Mr. Kilgour phrase a statement of the problem on technological unemployment as he sees it and present it to the ISAD/LED Education Committee for consideration as the program theme at the New York conference. SECONDED by Mrs. Martin. CARRIED.

PROPOSED STANDARDS IN JOLA TC. Mr. John Kountz brought up the subject of using JOLA TC for the interactive mechanism of presenting the proposal of a standard to the ISAD members for comment, and of having a form included to be filled out and returned. The board agreed that this was a good idea.

ISAD/LED EDUCATION COMMITTEE REPORT. Ann Painter, chairman, asked for clarification of appointment of new members to the committee. Roger Greer is the only member whose term continues past this year. Mr. Hammer was asked to find out who appoints members to the above committee.

The committee is working on a series of papers defining educational "modules" and has sent out a revised questionnaire to identify appropriate subject areas. It is planning to send the questionnaires to associated institutions as well as to the ALA accredited schools.

The need for funding the modules rather than depending upon volunteer or "slave labor" was considered by the committee. Volunteers have litthe preparation time and so often there is a lack of in-depth or consistency in developing these modules. Also the committee would like to set up a file of modules available to people across the country. There could be a problem of copyright involved.

Mr. Kilgour asked Miss Painter for suggestions of people who might be interested in serving on the committee.

JOLA MANUSCRIPTS. Mrs. Martin, editor of JOLA, asked the board for its feeling on whether it would be appropriate or desirable to put the date of acceptance on published manuscripts in JOLA. The board decided that should be the editor's decision.

VOTE OF THANKS TO MRS. MARTIN. The board gave Mrs. Susan Martin a unanimous vote of thanks for her work in getting the issues of JOLA caught up to date in time to meet the Post Office deadline of December 31,1973 in order to retain the second class permit. 


\section{REPORT OF THE MEMBERSHIP SURVEY COMMITTEE. (See Exhibit 5.)}

BOARD MINUTES IN JOLA. The board suggested that minutes published in JOLA be entitled "Highlights of ISAD Board Meeting" rather than minutes. The meeting was adjourned at 12:30 p.m.

\section{EXHIBIT 1}

\section{PROPOSAL FOR ESTABLISHING ON A SUBSCRIPTION BASIS A SELECTIVE DISSEMINATION OF INFORMATION SYSTEM FOR ALA MEMBERS}

The original proposal for an SDI system was intended for ISAD members only, but interest has grown at ALA Headquarters to the extent that it is being considered as a service to be provided for all ALA members. The proposal therefore does not require any action on the part of the ISAD Board. It is presented here for information and to give the board members an opportunity to comment on the idea and make suggestions toward developing the best possible procedure.

It is hoped that a presently operating system can be found that would enable ALA members to subscribe to a system using multisubject data banks that would automatically adjust profiles according to past output results and that would supply as requested copies of articles and documents whenever possible. Such documents would of course be supplied at a fee additional to the basic subscription fee. It is also hoped that the operators of the system would be responsive to subscriber feedback and would improve the system as warranted.

At present the only existing data banks in the library and information science fields are ERIC and MARC, but hopefully as time goes on others will be developed. It, for example, would seem prudent for the $\mathrm{H}$. W. Wilson Company to consider the sale of Library Literature in machine-readable form. In any event, there is no reason to limit subscriptions to the service to information science data banks. If interested, members of ALA could subscribe to other subject fields depending upon the data banks made available by the operating service. Chemistry librarians could, if useful to them, subscribe to Chemical Abstracts Condensates, engineering librarians to Engineering Index, etc., etc. Only time and the availability of SDI can determine the interest of librarians in such services.

At the time of writing, only one of the two agencies contacted for information has provided descriptive data on their system. A copy of one of the papers sent by the UCLA Center for Information Services is attached. Ohio State University libraries had not as yet responded. Enquiries will be made with other operating systems so that a basis for comparison will be available for decision at ALA Headquarters.

Comments and suggestions from ISAD Board members would be appreciated. Information regarding presently operating systems would also be of great value.

December 13, 1973

\section{EXHIBIT 2}

REPORTS OF THE MEETINGS OF THE MARBI COMMITTEE (Interdivisional Committee on Representation in Machine Readable Form of Bibliographic Information) January 19 and 20, 1974

Number one priority was the resolution of the relationship between the Library of Congress and MARBI in its capacity as the MARC Advisory Group. 


\section{Journal of Library Automation Vol. 7/1 March 1974}

There was discussion of the position paper which was presented at the Las Vegas meeting (copy attached) entitled "The Library of Congress View on Its Relation to the ALA MARC Advisory Committee."

LC had revised certain portions of this paper to conform with MARBI's wishes. These revisions were acceptable to the committee. There was concern, however, over an addition which pertained to MARBI's role with regard to formats other than books and serials (namely films, maps, music, etc.) Alternate wording to LC's proposal was worked out by Paul Fasana and John Knapp.

Several documents were submitted by Henriette Avram: (1) A proposed document numbering scheme for communications between LC and the committee and vice versa, and (2) Proposed format for presenting changes to MARC formats (copies attached). These documents and proposals were acceptable to the committee.

(Note: Incidental to this discussion, the committee officially adopted "MARBI" as its official acronym.)

1. The LC liaison presented two proposed MARC format changes for the committee's consideration entitled:

LC/MARBI 2-Addition of $\$ \mathrm{x}$ subfield for $4 \mathrm{xx}$ fields to allow for ISSN.

LC/MARBI 3-Specification of the 830 field.

The committee decided that the following plan of action would be followed with regard to these two changes:

They would be announced and distributed to ISAD MARC Users' Discussion group at its January 21,1974 meeting.

The proposed changes would be sent to all on MUDG's mailing list, asking for replies to the MARBI Chairman by February 16, 1974.

The chairman would summarize responses and poll MARBI committee members who would respond by March 16, 1974.

The MARBI committee chairman would respond to LC by March 16, 1974.

MARBI will request publication of changes in JOLA Technical Communications.

2. Henriette Avram presented to the committee a CLR statement which had been presented to ARL entitled "A Composite Effort to Build an On-Line National Serials Data Base."

The committee took note of the presentation with interest and voted to take no action on the matter at the January 19 meeting.

3. The Character Set Subcommittee of MARBI reported that it had issued a written report which will be used in support of the United States position concerning development of standards within the International Standard organization.

MARBI issued thanks to the subcommittee and requested that they remain convened pending review of further developments coming from activities within ISO.

4. There was a report on activities of the ad hoc committee convened by CLR to discuss use of the MARC format in a network environment. A paper entitled "Sharing Machine Readable Bibliographic Data: A Progress Report on a Series of Meetings Sponsored by the Council on Library Resources" was discussed.

The committee took note of these activities with interest and will wait for formal submission of format changes from the Library of Congress.

5. MARBI discussed the apparent overlap of the change between MARBI and the new ISAD Committee on Technical Standards. MARBI passed a resolution that the ISAD representatives should bring to the attention of the ISAD Board its concern over the similarity of the function statements of the two committees, and asked that these apparent discrepancies be considered and any duplication be eliminated.

6. The proposed MARBI Serials task force was discussed. It was felt that MARBI committee members needed to keep up on developments, and that the chairman should continue to collect and distribute as much documentation as possible to the committee 
members. It was decided that there was no need at this time to set up a separate subcommittee to perform this function.

7. The proposed amendments to ISO 2709-1973(E) were discussed.

It appears that there are several proposals circulating to change this standard.

MARBI formed a subcommittee to study these proposals and respond, and possibly, to make counterproposals. The position of MARBI will be reported to the chairman of ANSI Z-39, SC/2 and will be used in support of the U.S. position within ISO. Any committee member or interested professional may reply individually. The subcommittee appointed consists of Charles Payne, John Knapp, Mike Malinconico, and Charles Husbands. Response will be made by April 1, 1974.

At its regular scheduled meeting, on January 20, all members were present. (John Byrum was unable to attend the unofficial meeting on January 19.)

The distribution of the RTSD and ISAD manual material was discussed.

The discussion of the previous day was summarized for purposes of review and for the benefit of the nonmembers attending the meeting.

1. MARBI and LC

The alternative wording to the LC position paper was presented by Paul Fasana. It was passed.

Henriette Avram will have it published in $L C I B$ and will submit it to JOLA TC. LRTS will also receive a copy. The paper will be submitted to each divisional board.

2. The national on-line union file of serials was discussed. Larry Livingston answered questions.

3. The Character Set Subcommittee report will see that ISAD has a copy. Interested professionals should ask for a copy from them.

4. The activities of the ad hoc CLR committee were again reviewed.

5. The ISAD Standards committee was discussed.

6. The Serials task force for MARBI was reported on.

7. The proposed changes to ISO 2709-1973 (E) were reviewed.

New Business:

8. The activity of the IFLA working group on content designators was discussed. It was reported that there is an attempt to standardize content designators across national boundaries, for purposes of international exchange. There are problems in the area of cataloging rules, not all libraries participating, and language.

No action was needed, as this is only for informational purposes at this time.

9. Location codes were discussed, but the issue was tabled pending report of ad hoc CLR committee.

10. Language and geographic area codes were brought up but not considered necessary to become involved.

11. The Z39 Standard Account Number (SAN) was reported by Emery Koltay.

12. Progress in regard to the publication of the ISBD-M and $S$ was discussed.

\section{EXHIBIT 3}

\section{COLA REPORT-MIDWINTER '74}

About fifty people were in attendance at portions of the four-hour meeting.

The first half was taken up by a series of informal presentations about activity

\section{AT:}

Stanford

CSUC

Berkeley \& ULAP

ULAP CIS Project at UCLA
BY:

Allen Veaner

John Kountz

Sue Martin

Peter Watson 


\section{Journal of Library Automation Vol. 7/1 March 1974}

AT:

NYPL-RLG \& SUNY Plans

University of Chicago

LC
BY:

Mike Malinconico

Charles Payne

Rob McGee

Mary Kay Daniels

Questions were entertained at the end of each presentation.

The second half was opened by a few announcements by Maryann Duggan about the New Orleans Institute and Henriette Avram about the serials proposals.

The major portion of the second half consisted of a panel discussion by John Kountz, Emery Koltay, Tom Brady, and John Knapp on the communication of orders, claim reports, ILL requests and responses in machine-readable form. John Kountz addressed general system design aspects, Emery Koltay discussed the ISBN, ISSN, and standard account numbers, Tom Brady discussed B\&T's experiences with BATAB, and John Knapp addressed the nature of the data elements and the record structure itself. Considerable discussion followed the presentations, centering heavily on the ISBN and its good points and failings.

Both parts of the meeting seemed to be well received. The major value of COLA seems to be as an occasion for a wide variety of automation-oriented people to discuss a similarly wide variety of topics in an informal environment. There was some feeling that the presentations in the first half could have been more tightly controlled.

The presentation in the second half was quite useful, I feel. I would like to suggest COLA as a good sounding-board for proposals and place for announcements, distributions of handouts or written position papers. John Kountz and I have discussed setting aside a portion of it for TESLA reports.

Respectfully submitted, Brian Aveney

\section{EXHIBIT 4}

TO: Board of Directors, Information Science and Automation Division

FROM: John Kountz, Chairman, Committee on Technical Standards for Library Automation

SUBJECT: Report of Committee's Activities, ALA Midwinter Meeting, 1974

The Committee on Technical Standards for Library Automation (TESLA) held its inaugural meetings on Tuesday, January 1974 (4:30-6:00 p.m. and 8:30-11:00 p.m.). These were icebreaker meetings for a new group. In view of the interest that had been expressed in various quarters, several interested observers attended, as well as six of the seven committee members (for membership attendance see attached list). In addition, the following individuals were invited to meet with the committee and present their review of standards activities in other areas; establish a working perspective for the committee within the American Library Association; and delineate the constraints of the committee's charge: Mr. Fred Kilgour, Mr. Don Hammer, Ms. Velma Veneziano, Mr. Emery Koltay.

While the specific discussion that ensued covered a variety of topics, the central objectives for these two meetings (establishing/defining action areas, constraints, roles, and reviewing in some detail the committee's charge) were met. In addition, stress was placed throughout the discussion on differentiating between professional, service, bibliographic, and similar library standards, and the communications/clearinghouse function to be served by the committee in its dealings with technical standards impacting library automation. 
At its next meeting, the committee can be expected to complete its deliberations on the charge, complete a proposed pilot procedure for the handling of initiative/reactive requirements for standards, and recommend a shakedown of the proposed procedure.

Committee on Technical Standards for Library Automation

ALA Midwinter Meeting 1974

Attendees of Meetings held 21 January 1974

Dr. Edmund A. Bowles, IBM

Mr. Arthur Brody, Bro-Dart Industries

Mr. Jay Cunningham, University of California

Mr. John Kountz, Chairman, California State University and Colleges

Mr. Tony Miele, Illinois State Library

Mr. Richard Utman, Princeton University

Absent:

Ms. Madeline Henderson, National Bureau of Standards

\section{EXHIBIT 5}

\section{REPORT OF THE MEMBERSHIP SURVEY COMMITTEE}

We mailed out 4,337 questionnaires as of November 3. As of last week, we had received 1,666 replies. They have now dwindled down to about five or six a day, so I feel we have probably received the majority of responses from our mailing. I hope for about a 40 percent response.

The returns are presently being coded now by my graduate assistant, and the University of South Carolina Computer Centre will keypunch them for us. I am hopeful that we can start analyzing the results by the end of February, and have the report ready for you by April.

The expenses to date have been:

$$
\begin{array}{cl}
\$ 346.95 & \text { preliminary mailing } \\
164.32 & \text { printing of envelopes } \\
166.60 & \text { return postage } \\
\$ 677.88 &
\end{array}
$$

The bill for printing the questionnaire hasn't been received yet but should be a very minor one. Jim Williams will write the program for the data, and the library school has computer time which we can use. I expect when all the expenses are in that the total will be more than the budgeted $\$ 700$, but not very much more.

Submitted by: Elspeth Pope, Chairman

Jim Williams

Bill Summers

Martha Manheimer 